\title{
Gambaran Tingkat Depresi pada Lansia di Wilayah Kerja Puskesmas Guguak Kabupaten 50 Kota Payakumbuh
}

\author{
Anissa, $\mathrm{M}^{1}$, Amelia, $\mathrm{R}^{2}$, dan Dewi, N.P ${ }^{3}$ \\ ${ }^{1}$ Bagian Psikiatri, Fakultas Kedokteran Universitas Baiturrahmah, Padang Indonesia \\ E-mail : mutiaraanissa@fk.unbrah.ac.id \\ ${ }^{2}$ Bagian Anatomi, Fakultas Kedokteran Universitas Baiturrahmah, Padang, Indonesia \\ ${ }^{3}$ Bagian Farmakologi Fakultas Kedokteran Universitas Baiturrahamah, Padang, Indonesia \\ ${ }^{4}$ Bagian Anatomi Fakultas Kedokteran Universitas Baiturrahmah, Padang, Indonesia
}

\begin{abstract}
Abstrak
Latar belakang: Depresi merupakan gangguan mental yang sering ditemukan pada lansia. Gejala depresi pada lansia sering tertutupi oleh gejala fisik. Depresi pada lansia dipengaruhi oleh berbagai faktor seperti boilogi, psikologi dan sosial. Depresi dapat semakin menurunkan kualitas hidup pada lansia. Tujuan: Penelitian ini bertujuan untuk mengetahui gambaran tingkat depresi pada lansia di wilayah kerja Puskesmas Guguak Kabupaten 50 Kota Payakumbuh. Metode: Penelitian merupakan suatu studi observasional yang bersifat deskriptif. Observasi terhadap 30 subyek dilakukan pada tanggal 7 April 2018. Hasil: Pada penelitian didapatkan subyek penelitian terdiri atas 8 orang laki-laki $(11,3 \%)$ dan 22 orang perempuan (73,3\%). Rata-rata umur subyek adalah 69,3. tahun. Tingkat pendidikan terbanyak pada subyek penelitian adalah SMA (40\%). Pasien terbanyak tidak memiliki riwayat penyakit medis lainnya (60\%). Pada penelitian diperoleh 33,3\% lansia mengalami depresi. Tingkat depresi yang dialami adalah depresi ringan $(23,3 \%)$ dan depresi berat $(10 \%)$. Kesimpulan: 33,3\% lansia mengalami depresi. Tingkat depresi yang dialami adalah depresi ringan $(23,3 \%)$ dan depresi berat $(10 \%)$.
\end{abstract}

Katakunci — depresi, lansia, kualitas hidup

\begin{abstract}
Background: Depression is a mental disorder that is often found in the elderly. Symptoms of depression in the elderly are often covered by physical symptoms. Depression in the elderly is influenced by various factors such as biology, psychology and social. Depression can further reduce the quality of life in the elderly. Objective: To determine the description of the Depression Rate in the Elderly in the Guguak Health Center Working Area District 50 Payakumbuh City. Method: The study is a descriptive observational study and observed on 30 subjects were carried out on April 7, 2018. Result: In the study, the subjects were 8 men (11.3\%) and 22 women (73.3\%). The average subject age is 69.3. year. The highest level of education in the study subjects was high school (40\%). Most patients did not have a history of other medical diseases (60\%). In the study, $33.3 \%$ of the elderly were depressed. The levels of depression experienced were mild depression (23.3\%) and major depression (10\%). Conclusion: $33.3 \%$ of the elderly were depressed. The levels of depression experienced were mild depression (23.3\%) and major depression
\end{abstract}

Keywords - depression, elderly, quality of life 


\section{Pendahuluan}

Peningkatan Usia Harapan Hidup akan menyebabkan meningkatnya jumlah lanjut usia (lansia) di Indonesia setiap tahunnya. Berdasarkan data proyeksi penduduk, diperkirakan tahun 2017 terdapat 23,66 juta jiwa penduduk lansia di Indonesia $(9,03 \%)$. Diprediksi jumlah penduduk lansia tahun 2020 (27,08 juta), tahun 2025 (33,69 juta), tahun 2030 (40,95 juta) dan tahun 2035 (48,19 juta). ${ }^{1}$

Besarnya jumlah penduduk lansia di Indonesia di masa depan membawa dampak positif maupun negatif. Berdampak positif, apabila penduduk lansia berada dalam keadaan sehat, aktif dan produktif. Namun, besarnya jumlah penduduk lansia menjadi beban jika lansia memiliki masalah penurunan kesehatan yang berakibat pada peningkatan biaya pelayanan kesehatan, penurunan pendapatan/penghasilan, peningkatan disabilitas, tidak adanya dukungan sosial dan lingkungan yang tidak ramah terhadap penduduk lansia. ${ }^{1}$

Peningkatan jumlah lansia membutuhkan penanganan yang serius karena secara alamiah lansia mengalami penurunan baik dari segi fisik, biologi maupun mentalnya. Hal ini tidak terlepas dari masalah ekonomi, sosial dan budaya, sehingga memerlukan peran serta keluarga dan adanya peran sosial dalam penanganannya. ${ }^{2}$

Salah satu gangguan kesehatan yang dapat muncul pada lansia adalah gangguan mental. Gangguan mental yang sering muncul pada masa ini adalah depresi, gangguan kognitif, fobia, dan gangguan pemakaian alkohol. Gangguan mental pada lansia dapat menyebabkan dampak yang besar bagi lansia, antara lain dapat menurunkan kemampuan lansia dalam melakukan aktivitas sehari-hari, menurunkan kemandirian dan kualitas hidup lansia.,
Pada lansia, depresi lebih sering terjadi dibandingkan pada populasi umum. Depresi pada pasien berusia di atas 60 tahun sering menampilkan dengan gejala tidak spesifik atau tidak khas. Hal tersebut menyebabkan kesulitan identifikasi sehingga depresi terlambat untuk diterapi. Selain itu depresi pada usia lanjut sering tidak diakui pasien dan tidak dikenali dokter karena gejala yang sering komorbid dengan penyakit medis lain sehingga lebih menonjolkan gejala somatik daripada gejala depresinya. ${ }^{2}$

Berbagai hasil penelitian yang dilakukan oleh Livingstone dkk, menunjukkan adanya tendensi peningkatan prevalensi gangguan depresi pada lansia. Hal ini terjadi karena merupakan hasil interaksi dari berbagai faktor biologis, psikologis, dan sosial. ${ }^{4}$

Berdasarkan data Riskesda 2007, Payakumbuh menempati 10 besar kota dengan penduduk berusia 15 tahun ke atas yang mengalami gangguan mental emosional. Data Riskesda juga memaparkan bahwa gangguan mental emosional ini $50 \%$ dialami penduduk usia diatas 60 tahun. Gangguan mental emosional dapat berupa depresi, cemas, insomnia dan gangguan lainnya. $^{5}$

\section{Metode Penelitian}

Penelitian ini merupakan suatu studi observasional yang bersifat deskriptif pada 20 lansia yang berkunjung ke Puskesmas Guguak 50 Kota Payakumbuh pada tanggal 7 Januaei 2018. Tingkat depresi dinilai dengan melakukan wawancara berdasarkan instrumen Geriatric Depression Scale (GDS). Hasil penilaian GDS dalam bentu tidak depresi, depresi ringan, depresi sedang dan depresi berat.

Populasi adalah semua lanjut usia yang berobat ke Puskesmas Guguak 50 Kota Payakumbuh pada tanggal 7 April 2018. Populasi terjangkau adalah semua lanjut usia yang berobat ke Puskesmas Guguak 50 Kota 
Payakumbuh pada tanggan 7 april 2018. Pengambilan sampel dilakukan secara consecutive sampling. Kriteria inklusi penelitian ini adalah pasien berusia $\geq 60$ tahun dan bersedia ikut penelitian (inform consent).

\section{HASIL}

Penelitian dilakukan pada 20 lansia yang berkunjung ke Puskesmas Guguak 50 Kota Payakumbuh pada tanggal 7 Januaei 2018.

\section{A. Karakteristik Dasar Subyek Penelitian}

Karakteristik dasar subyek penelitian dapat dilihat pada Tabel 1.

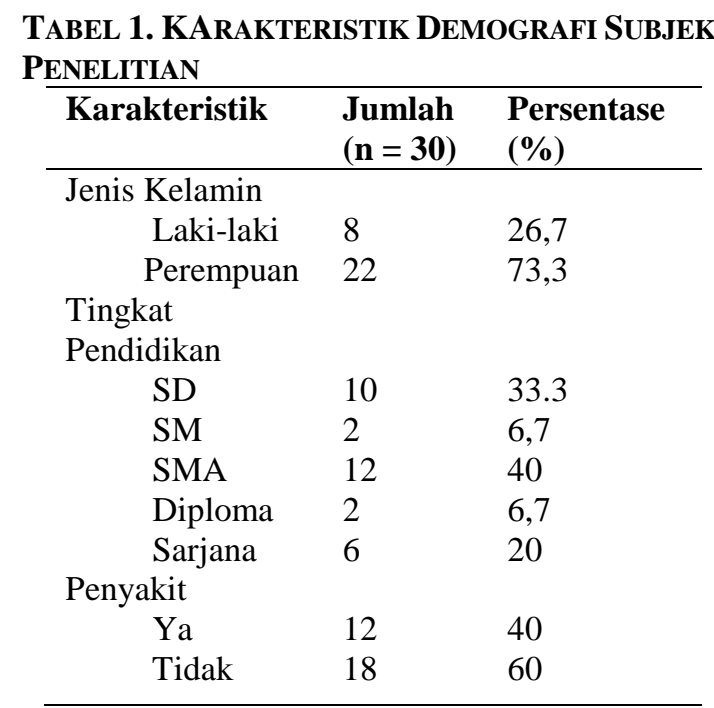

Pada penelitian didapatkan subyek penelitian terdiri atas 8 orang laki-laki $(11,3 \%)$ dan 22 orang perempuan $(73,3 \%)$. Rata-rata umur subyek adalah 69,3. tahun. Tingkat pendidikan terbanyak pada subyek penelitian adalah SMA (40\%). Pasien terbanyak tidak memiliki riwayat penyakit medis lainnya $(60 \%)$.

\section{B. Karakteristik Demografi pada Responden Yang Mengalami Depresi}

TABEL 2. KARAKTERISTIK DEMOGRAFI PADA RESPONDEN YANG MENGALAMI DEPRESI

\begin{tabular}{cll}
\hline Karakteristik & $\begin{array}{l}\text { Jumlah } \\
(\mathbf{n = 1 0})\end{array}$ & $\begin{array}{l}\text { Persentase } \\
(\boldsymbol{\%})\end{array}$ \\
\hline Jenis Kelamin & & \\
Laki-laki & 5 & 50 \\
Perempuan & 5 & 50 \\
& & \\
Tingkat Pendidikan & & \\
SD & & \\
SMP & 4 & 33.3 \\
SMA & 1 & 6,7 \\
Diploma & 4 & 40 \\
Sarjana & 0 & 6,7 \\
Penyakit & 1 & 20 \\
Ya & & \\
Tidak & 6 & 60 \\
& 4 & 40 \\
\hline
\end{tabular}

Berdasarkan jenis kelamin, jumlah lansia yang mengalami depresi sama antara lakilaki dan perempuan. Lansia yang mengalami depresi banyak ditemukan pada tamatan SD dan SMA. Lansia yang mengalami depresi memilik riwayat penyakit umum lainnya yaitu $60 \%$.

\section{Tingkat Depresi Subyek Penelitian}

TABEL 3. KARAKTERISTIK TINGKAT DEPRESI PADA SUbYeK PENELITIAN

\begin{tabular}{lll}
\hline Jenis Gangguan Depresi & $\begin{array}{l}\text { Jumlah } \\
(\mathbf{n = 3 0})\end{array}$ & $\begin{array}{l}\text { Persentase } \\
(\mathbf{\%})\end{array}$ \\
\hline Normal & 20 & 66,7 \\
Depresi ringan & 7 & 23,3 \\
Depresi sedang & 0 & 0 \\
Depresi berat & 3 & 10 \\
\hline
\end{tabular}

Pada penelitian diperoleh $33,3 \%$ lansia mengalami depresi. Tingkat depresi yang dialami adalah depresi ringan $(23,3 \%)$ dan depresi berat (10\%).

\section{Pembahasan}

Berdasarkan penelitian, diperoleh 30 lansia yang terdiri atas 8 orang laki-laki dan 22 orang perempuan. Pada responden diperoleh $66,7 \%$ tidak mengalami depresi dan 33,3\% mengalami depresi. Hal ini sesuai dengan penelitian yang dilakukan Bayu Rizky di Puskesmas Babakan yaitu $42 \%$ responden mengalami depresi. Angka ini cukup tinggi dibandingkan penelitian Licinio yang memperoleh prevalensi depresi 0,4-35\%. ${ }^{6}$

Penyebab gangguan depresi adalah 
multifaktorial yaitu kontribusi dari biologi, psikologi dan social. Ditinjau dari biologik perubahan neurotransmiter otak, yaitu antara lain: norepinefrin, serotonin dan dopamine. Faktor psikologi dapat dipengaruhi oleh kepribadian lansia yaitu ciri kepribadian dependen, cemas menghindar dan anankastik. Sedangkan pengaruh faktor sosial dikarenakan rasa kesepian, rasa tidak berguna atau masalah keuangan.,

Berdasarkan jenis kelamin, jumlah lansia yang mengalami depresi sama antara lakilaki dan perempuan. Hasil ini berbeda dengan penelitian Ivone di Menado yang mana lansia depresi lebih banyak pada perempuan. Hal ini diperkirakan karena jumlah sampel lansia laki-laki yang tidak hadir saat pelayanan kesehatan. Hal ini juga tampak dari seluruh sampel terdiri dari 22 lansia perempuan dan 8 lansia laki-laki. ${ }^{8}$

Berdasarkan tingkat pendidikan, lansia yang mengalami depresi memiliki latar belakang pendidikan SD dan SMA. Hal ini seseuai dengan penelitian Ivone di Menado, yang memperoleh $27,6 \%$ responden berpendidikan rendah. pendidikan dapat mempengaruhi perilaku seseorang. Semakin tinggi pendidikan seseorang, maka ia akan semakin mudah menerima informasi sehingga semakin banyak pula pengetahuan yang dimiliki. ${ }^{8}$

Pendidikan merupakan modal awal dalam perkembangan kognitif, dimana kognitif tersebut dapat menjadi mediator antara suatu kejadian dan mood. Kognitif mendasari pikiran atau persepsi seseornag terhadak kejadian kehiupan. Persepsi atau pikiran negatif salah satu faktor risiko terjadinya depresi. $^{9}$

Pada penelitian diperoleh lansia dengan depresi memiliki riwayat penyakit lain atau kondisi medis umum lainnya. Hal ini sesuai dengan penelitian Aryawangsa di Bali bahwa depresi dengan lansia memiliki penyakit medis. Adanya penyakit medis merupakan salah satu stressor pada seseorang yang mampu untuk meningkatkan risiko terjadinya depresi. Penyakit fisik dapat mengakibatkan menurunnya kemampuan fisik dan fisiologis seseorang sehingga dapat menurunkan seseorang untuk beraktivitas seperti biasanya baik dalam bekerja maupun melakukan kegiatanfisik lainnya. Hal ini meningkatkan risiko depresi pada lansia. ${ }^{10}$

Depresi yang banyak dialami responden adalah depresi ringan (23,3\%). Hasil penelitian ini sesuai dengan penelitian yang dilakukan oleh Livana dkk (2018) yang mendapatkan 41,6\% yang mengalami depresi ringan.. Pada penelitian ini sebgain lansia dnegan depresi memiliki tingkat pendidan SMA. Lansia dengan pendidikan SMA memiliki persepsi yang lebih baik dalam memandang kehidupan dibanding lansia dengan tingkat pendidikan SD. ${ }^{11}$

Lansia di daerah Guguak memiliki aktivitas fisik seperti ke masjid atau ke sawah. Penelitian oleh Sanjaya dan Rusdi pada tahun (2012) menunjukkan bahwa keterlibatan sosial mempunyai efek yang positif pada kesejahteraan emosional lansia dan kesehatan fisik. Perilaku yang aktif dari lansia ternyata dapat mempertinggi daya hidupnya dan mendapatkan kepuasan serta kesenangan batin dalam mengisi kehidupan lanjut usianya. Aktivitas sosial didefinisikan sebagai kegiatan yang dilakukan bersama dengan masyarakat di lingkungan sekitar. $^{12,13}$

\section{KeSimpulan Dan SARAN}

Pada penelitian diperoleh $33,3 \%$ lansia mengalami depresi dengan tingkat depresi yang paling banyak dialami adalah depresi ringan. Keterbatasan penelitian adalah sampel yang sedikit. Saran peneliti adalah penelitian dilakukan dengan sampel lebih banyak dan mencari faktor risiko yang berhubungan dengan depresi pada lansia. 


\section{Daftar Pustaka}

[1] Kementrian Kesehatan RI, Analisis Lansia di Indonesia. Diakses dari www.depkes.go.id\%2Fdownload.php\%3Ffile\%3 Ddownload\%2Fpusdatin\%2Flainlain\%2FAnalisis\%2520Lansia\%2520Indonesia\% 25202017.pdf\&usg=AOvVaw1pZHfpZoN-XHDuoHyy3HF.

[2] Kusumowardany, A. Puspitorsari, A. Hubungan Antara Tingkat Depresi Lansia Dengan Interaksi Sosial Lansia Di Desa Sobokerto Kecamatan Ngemplak Boyolali. Jurnal Terpadu Ilmu Kesehatan, Volume 3, No 2, November 2014, hlm 106-214.

[3] Nugroho, E. N. Mengenali Depresi pada Usia Lanjut Penggunaan Geriatric Depression Scale (GDS) untuk Menunjang Diagnosis. 2014. CDK217/ vol. 41 no. 6.

[4] Sadock, B. J. Sadock, V.A. Kaplan \& Sadock's Synopsis of Psychiatry: Behavioral Sciences/Clinical Psychiatry. Edisi 10. Lippincott Williams \& Wilkins. 2007.

[5] Badan Penelitian Dan Pengembangan Kesehatan Kementerian Kesehatan RI. Riskesdas 2013. Diakses dari http://www.depkes.go.id/resources/download/gen eral/Hasil\%20Riskesdas\%202013.pdf.

[6] Bayu Rizky Riannisa. Gambaran Tingkat Depresi Pada Lansia Di Kelurahan Babakan Sari Wilayah Kerja Puskesmas Babakan Sari Kota Bandung. $2012 . \quad$ Diakses dari http://jurnal.unpad.ac.id/ejournal/issue/view/149.

[7] Syamsir B.S. Gangguan Depresif pada Orang Usia Lanjut. Departemen Psikiatri Fakultas Kedokteran Universitas Sumatera Utara/RS Haji Adam Malik, Medan. 2007. Majalah Kedokteran Nusantara Volume 40 No. 2.

[8] Ivone R, Theresia M, Herdy M, Christoffel E. Profil Lanjut Usia Dengan Depresi Yang Tinggal Di Balai Penyantunan Lanjut Usia Senja Cerah Manado. Jurnal Biomedik, Volume 4, Nomor 1, Maret 2012, hlm. 59-67.

[9] Irawan, H. Gangguan Depresi pada Lanjut Usia. CDK-210/ vol. 40 no. 11. 2013.

[10] Aryawagsa AA, Ariastuti NLP. Prevalensi dan Distribusi Faktor Risiko Depresi pada Lansia di Wilayah Kerja Puskesmas Tampaksiring, Kabupaten Gianyar Bali. ISM : vol. 7no.1, september-desember, hal 122312http://isainsmedis.id/ojs/2015.

[11]Livana PH, Yulia S, Lestari E. T Gambaran Tingkat Depresi Lansia. Jurnal Keperawatan dan Pemikiran I. 4(4).80-93

[12] Suardana, I.W. Hubungan Faktor Sosiodemografi, Dukungan Sosial, dan Status Kesehatan dengan Tingkat Depresi pada Agregat Lanjut Usia di Kecamatan Karangasem, Kabupaten Karangasem, Bali. Fakultas Ilmu Keperawatan Universitas Indonesia; 2011.
Available from URL: http://lib.ui.ac.id/file?file=digital/201282773-T20Wayan\%20Suardana.pdf. Accessed: April 20, 2015.

[13] Sanjaya, A., dan Rusdi, I. 2012. Hubungan Interaksi Sosial Dengan Kesepian Pada Lansia. Jurnal Keperawatn Holistik, Vol. 1(3): pp.26-31. 